\title{
Clarithromycin Genotoxicity in Mice
}

\author{
Aziza, A. E. Ibrahim* and Kawser M. El-Sherbeny \\ Department of Genetics and Cytology, National Research Centre, Dokki, Cairo, Egypt
}

Received October 20, 2005; accepted December 22, 2005

\begin{abstract}
Summary The effect of clarithromycin on the induction of chromosome aberrations in mice bonemarrow, splenocyte cells and spermatocyte cells was investigated. Male Swiss mice were orally treated by gavage once with doses $50,100,200$ and $300 \mathrm{mg} \mathrm{kg}^{-1}$ b.wt. A repeated daily dose of 50 $\mathrm{mg} \mathrm{kg}^{-1}$ b.wt. was given for successive days. Clarithromycin induced chromosome aberrations in both bone-marrow and splenocyte cells. The percentage of chromosome aberrations was found to be statistically significant after single and repeated treatments.

The percentage of chromosome aberrations in diakinesis-metaphase I spermatocytes increased in a dose dependent manner and was found to be statistically significant after 2 higher and repeated doses.

The high doses of the antibiotic caused a significant increase in the frequency of sister chromatid exchanges in mice bone-marrow. Its highest values were $9.99 \pm 0.48$ /cell after treatment with high dose ( $300 \mathrm{mg} \mathrm{kg}^{-1}$ b.wt.) compared with $4.24 \pm 0.44 /$ cell in the non treated mice.
\end{abstract}

Key words Genotoxicity, Clarithromycin, Chromosome aberrations, Mice.

The newer macrolides have added effectiveness against gram-negative bacteria and anaerobes. Macrolides are of tremendous value for their unique ability to treat atypical pathogens seen in community acquired pheamonias (Laurence et al. 1997).

Clarithromycin is a newer macrolide antibiotic which appears to have significant increase potency against many gram positive and negative aerobic and anaerobic organisms. It is indicated in the treatment of infections caused by microorganisms sensitive to clarithromycin e.g. pharyngits, tonsillitis, acute maxillary sinusitis, acute bacterial exacerbation of chronic bronchitis, bacterial pneumonia and atypical pneumonia, uncomplicated skin and skin structure infection (Delgado and Remers 1998).

The present work aims to shed some light on a mutagenic potential of clarithromycin in somatic and germ cells in the mice.

Materials and methods

Animals

Mature male Swiss mice, aged 9-12 weeks and weighted 25-30 gm obtained from a close random-bread colony at National Research Centre, were used.

\section{Chemical and treatment}

Clarithromycin was purchased from Sigma pharmaceutical industries S.A.E. Egypt. Clarithromycin (dissolved in distilled water) was administered by gavage at 4 different doses: 50, 100, 200 and $300 \mathrm{mg} \mathrm{kg}^{-1}$ b.wt. A dose of $50 \mathrm{mg} \mathrm{kg}^{-1}$ b.wt. is the therapeutic dose for humans (Delgado and Remers 1998).

\footnotetext{
*Corresponding author, Fax.: +2023370931, e-mail: farghaly-5@yahoo.com
} 

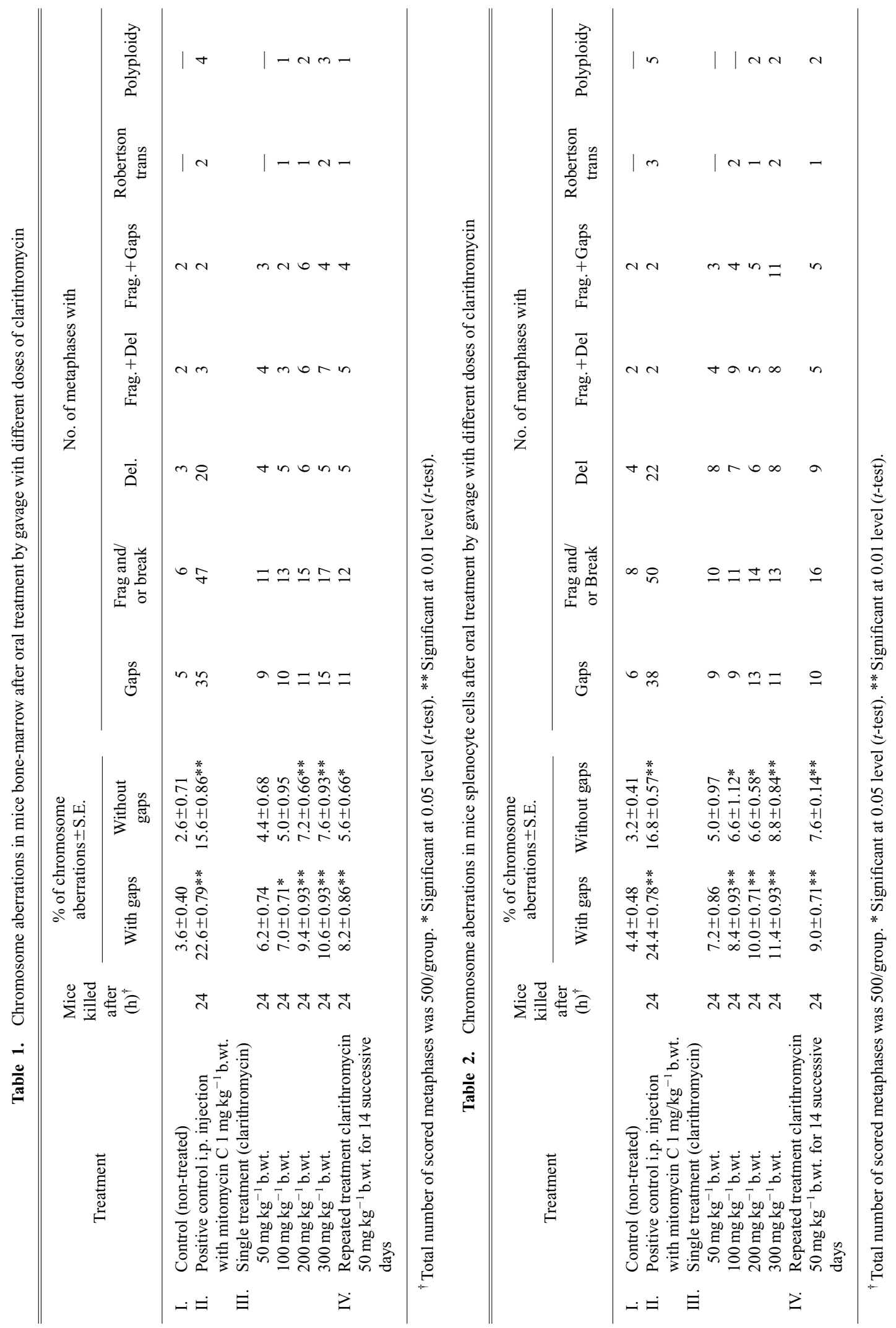


\section{Treatment and cytological preparation}

Chromosome aberration in somatic cells. For bone-marrow and splenocyte cells, a group of mice (5/dose) were orally treated with a single dose of 50, 100, 200 and $300 \mathrm{mg} \mathrm{kg}^{-1}$ b.wt. For repeated treatment, mice were orally treated daily for 14 successive days with $50 \mathrm{mg}$ clarithromycin $\mathrm{kg}^{-1}$ b.wt., samples were taken $24 \mathrm{~h}$ after post treatment.

Chromosomes from bone-marrow cells were prepared following the method of Yosida and Amano (1965) and from splenocyte cells were prepared according to Amer et al. (1993). Slides were stained with phosphate buffer Giemsa, 100 well spreaded metaphases were analyzed per animal.

Chromosome aberrations in germ cells. Spermatocyte metaphases at diakinase metaphase I was prepared according to Evans et al. (1964). Slides were stained with 7\% Giemsa stain in phosphate buffer $\mathrm{pH}$ 6.8. At least 100 well spread metaphases were analyzed for each animal, scoring different types of aberrations.

Sister chromatid exchanges (SCEs). For SCEs random-bread male swiss mice aged 3-4 months were used and method described by McFee et al. (1983) was followed. A subcutaneous implantation of 5-Bromodeoxyuridine (BrdU) tablet $(55 \mathrm{mg})$ was initially made in each mouse and $30 \mathrm{~min}$ later the test compound was administered by gavage. After $21 \mathrm{~h}$, the animals received an intraperitoneal injection of colchicine $\left(10 \mathrm{mg} \mathrm{kg}^{-1} \mathrm{~b}\right.$.wt.). Bone-marrow cells were fixed $24 \mathrm{~h}$ later and stained with fluorescence plus Giemsa method of Perry and Wolff (1974). Five animals were taken for each treatment and 40 well spread metaphases per animal were examined microscopically for SCEs.

In all experiments a negative control received only distilled water and mitomycin $\mathrm{C}$ at a dose $1 \mathrm{mg} \mathrm{kg}^{-1}$ b.wt. (i.p.) was used as a positive control.

Statistical analysis.:The significance of experimental versus control data was calculated using the $t$-test.

\section{Results}

\section{Chromosome aberrations}

Somatic cells. The different doses of clarithromycin induced an increase in the percentage of chromosome aberrations in both mice bone-marrow and splenocyte cells after a single and repeated oral treatments. This increase was statistically significant after oral treatment with the higher single doses and repeated dose for 14 consecutive days (Tables 1,2).

The types of aberrations observed in both mice bone-marrow and splenocyte cells were the same. Main type of aberrations was chromatid gaps, chromatid deletions, fragments and/or breaks. Robertsonian translocations and numerical chromosome aberrations in the form tetraploid cells were present in a few number (Tables 1, 2 and Fig. 1a).

Germ cells. Table 3 presents the frequencies and distributions of chromosome aberrations in spermatocyte cells after a single and repeated doses of clarithromycin. The percentage of aberrations was dose and time dependent.

The clarithromycin induced abnormal chromosome associations including X, Y and autosomal univalents as well as reciprocal translocations as chain IV (Table 3, Fig. 1-b).

\section{Sister chromatid exchanges (SCES)}

Clarithromycin induced dose dependent increase in SCEs frequency in mice bone-marrow cells. The frequency of SCEs was found to be statistically significant after oral treatment with the higher doses 100, 200 and $300 \mathrm{mg} \mathrm{kg}^{-1}$ b.wt. (Table 4, Fig. 1-c, d). 

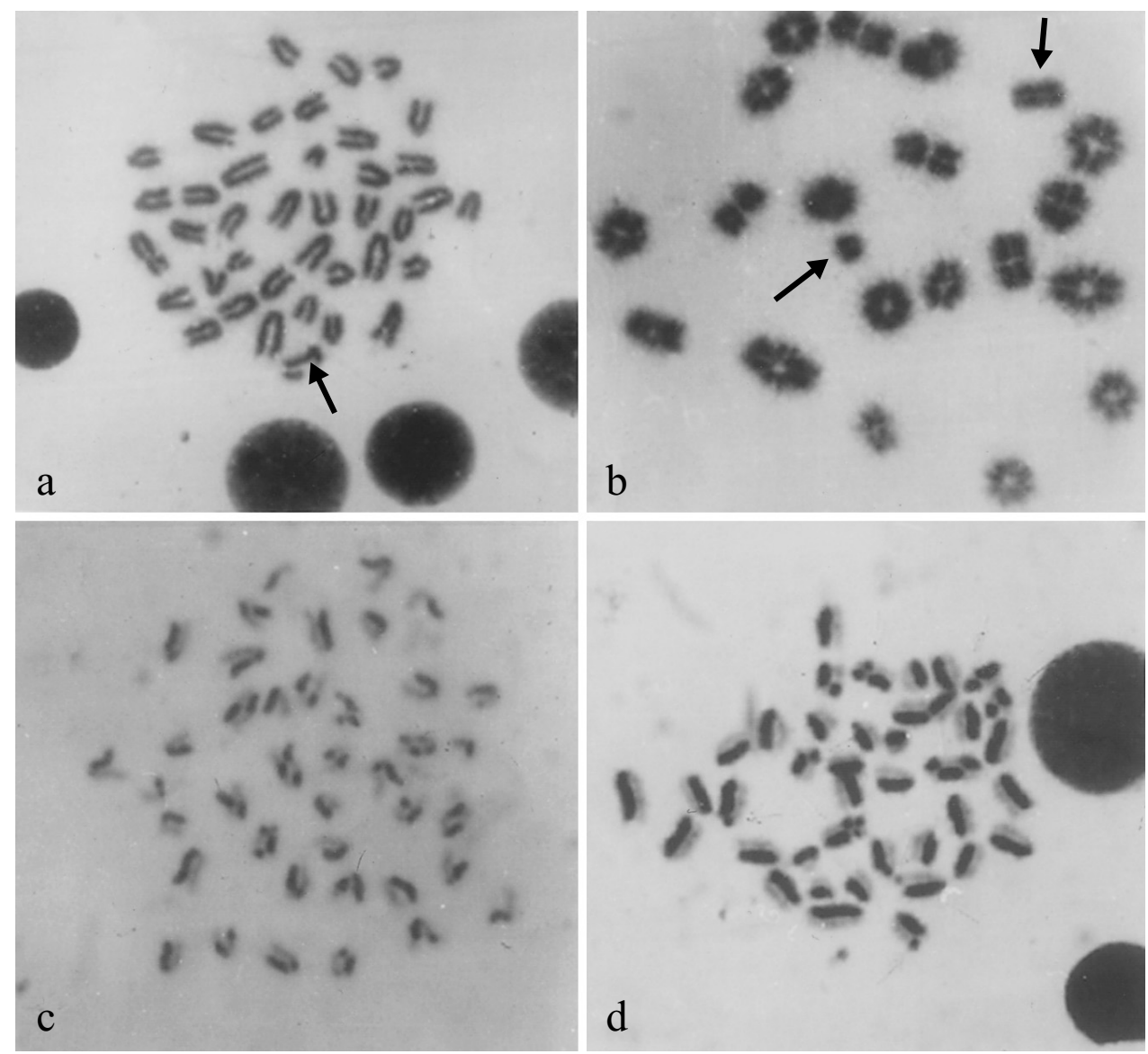

Fig. 1. Metaphases from mice treated with different doses $\left(100,200,300 \mathrm{mg} \mathrm{kg}^{-1} \mathrm{~b}\right.$.wt.) of clarithromycin. a) Chromatid break in mice splenocyte cells. b) X-Y univalent in mice spermatocyte. c, d) Metaphases from mice bone-marrow cells showing SCEs induced after treatment with clarithromycin.

\section{Discussion}

Drugs are considered to be an important group of chemicals. Recently there is a growing concern about possible genotoxic and mutagenic potential of drugs in mammalian cells (Mailhes et al. 1993, Donya 2002, Ibrahim 2003).

The different doses of clarithromycin induced an increase in the percentage of chromosome aberrations in both bone-marrow and splenocyte cells after a single and repeated oral treatment. Also, the percentage of chromosome aberrations increased significantly $(P<0.01)$ in bone-marrow and splenocyte cells after treatment of mice by gavage with $50 \mathrm{mg} \mathrm{kg}^{-1} \mathrm{~b}$.wt. clarithromycin for 14 successive days. In this connection, it may be mentioned that the same effect was observed after oral treatment with Diazepam (Fahmy and Aly 1995) Cefadroxil (Aly 2001), and Cefuroxime (Ibrahim 2003).

A single oral treatment with clarithromycin (therapeutic dose, $50 \mathrm{mg} \mathrm{kg}^{-1}$ b.wt.) was not significant in both somatic and germ cells. However, repeated treatment with the same dose (50 mg kg ${ }^{-1}$ b.wt.) was highly statistically significant in all types of cells. This may be attributed to the rapidly and completely absorbed from the gastrointestinal metabolism which is saturable $\left(t_{1 / 2}\right.$ is increased with the dose) (Laurence et al. 1997). 
Table 3. Frequency of chromosomal aberrations in primary spermatocytes of male mice induced after oral treatment with different doses of clarithromycin

\begin{tabular}{|c|c|c|c|c|c|c|c|c|}
\hline \multirow[b]{2}{*}{ Treatment } & \multirow{2}{*}{$\begin{array}{l}\text { Mice } \\
\text { killed } \\
\text { after } \\
(\mathrm{h})^{\dagger}\end{array}$} & \multirow{2}{*}{$\begin{array}{l}\% \text { of } \\
\text { chromosome } \\
\text { aberrations } \\
\pm \text { S.E. }\end{array}$} & \multicolumn{6}{|c|}{ No. of metaphases with } \\
\hline & & & $\begin{array}{c}\mathrm{X}-\mathrm{Y} \\
\text { univalent }\end{array}$ & $\begin{array}{c}\text { Autosomal } \\
\text { univalent }\end{array}$ & $\begin{array}{l}\text { X-Y } \\
+ \\
\text { A.u. }\end{array}$ & $\begin{array}{l}\text { Frag. and/ } \\
\text { or Break }\end{array}$ & Chain & Treploidy \\
\hline I. Control (non-treated) & & $3.4 \pm 0.67$ & 8 & 6 & 3 & - & 一 & - \\
\hline $\begin{array}{l}\text { II. Positive control i.p. } \\
\text { injection with mitomycin } \\
\mathrm{C} 1 \mathrm{mg} \mathrm{kg}^{-1} \text { b.wt. } \\
\text { III. Single treatment } \\
\text { (clarithromycin) }\end{array}$ & 24 & $21.0 \pm 0.76^{* *}$ & 47 & 38 & 10 & 2 & 3 & 5 \\
\hline $50 \mathrm{mg} \mathrm{kg}^{-1}$ b.wt. & 24 & $5.2 \pm 0.73$ & 11 & 9 & 4 & 1 & - & - \\
\hline $100 \mathrm{mg} \mathrm{kg}^{-1}$ b.wt. & 24 & $6.0 \pm 0.71^{*}$ & 16 & 15 & 1 & 2 & 2 & 5 \\
\hline $200 \mathrm{mg} \mathrm{kg}^{-1}$ b.wt. & 24 & $8.2 \pm 0.86^{* *}$ & 9 & 8 & 4 & 5 & 4 & 7 \\
\hline $300 \mathrm{mg} \mathrm{kg}^{-1}$ b.wt. & 24 & $9.8 \pm 0.86^{* *}$ & 18 & 13 & 3 & 7 & 4 & 4 \\
\hline $\begin{array}{l}\text { IV. Repeated treatment } \\
\text { clarithromycin } \\
50 \mathrm{mg} \mathrm{kg}^{-1} \text { b.wt. for } 14 \\
\text { successive days }\end{array}$ & 24 & $7.4 \pm 0.93 *$ & 15 & 7 & 6 & 2 & 3 & 3 \\
\hline
\end{tabular}

${ }^{\dagger}$ Total number of scored metaphases was 500/group. * Significant at 0.05 level ( $t$-test). ${ }^{* *}$ Significant at 0.01 level $(t-$ test).

Table 4. Frequency of sister chromatid exchanges (SCEs) in mice bone-marrow cells after oral treatment by gavage with different doses of clarithromycin

\begin{tabular}{|c|c|c|c|c|}
\hline & Treatments & Metaphases No. & SCEs No. & SCEs/cell Mean \pm S.E. \\
\hline I. & Control (non-treated) & 200 & 847 & $4.24 \pm 0.44$ \\
\hline II. & $\begin{array}{l}\text { Positive control i.p. injection with } \\
\text { mitomycin } \mathrm{C} 1 \mathrm{mg} \mathrm{kg}^{-1} \text { b.wt. }\end{array}$ & 200 & 2615 & $13.07 \pm 0.58^{* *}$ \\
\hline \multirow[t]{5}{*}{ III. } & Single treatment (clarithromycin) & & & \\
\hline & $50 \mathrm{mg} \mathrm{kg}^{-1}$ b.wt. & 200 & 1137 & $5.69 \pm 0.15$ \\
\hline & $100 \mathrm{mg} \mathrm{kg}^{-1}$ b.wt. & 200 & 1457 & $7.29 \pm 0.24 *$ \\
\hline & $200 \mathrm{mg} \mathrm{kg}^{-1}$ b.wt. & 200 & 1768 & $8.84 \pm 0.69 * *$ \\
\hline & $300 \mathrm{mg} \mathrm{kg}^{-1}$ b.wt. & 200 & 1997 & $9.99 \pm 0.48^{* *}$ \\
\hline
\end{tabular}

* Significant at 0.05 level ( $t$-test). ** Significant at 0.01 level ( $t$-test).

In this study, the percentage of chromosome aberration in diakinasis-metaphase I increased by increasing both the dose and the time of treatment. Univalents were the most common types of abnormalities in mouse spermatocyte cells after treatment with clarithromycin. The number of sex univalent aberration type was higher than the autosomal univalent aberration type. Numerous mutagens were shown to increase the frequency of chromosomal univalency in mouse spermatocytes (Allen et al. 1986). It should be noticed that $\mathrm{X}$ and $\mathrm{Y}$ were more often separated than autosomes. This phenomenon has been observed in spermatocytes of mice treated with other chemical agents, e.g. uranyl fluoride (Hu and Zhu 1990).

SCEs have proved to be a high sensitive indicator for assessing suspected mutagens or carcinogens. SCEs can be precisely scored and readily induced in mammalian cells by various known mutagens and carcinogens at concentration far below cytotoxic and clastogenic levels (Latt 1974, Perry and Evans 1975).

A single oral treatment with the higher doses of clarithromycin caused a significant increase in SCEs frequency. The frequency of SCEs per cell was found to be $9.99 \pm 0.48 /$ cell $(P<0.01)$ after 
oral treatment with $300 \mathrm{mg} \mathrm{kg}^{-1}$ b.wt. compared with $4.24 \pm 0.44 /$ cell for the control i.e. higher than the two fold of the control value. This indicate that clarithromycin is a strong inducer of SCEs in mice bone-marrow cells. This has been described for other drugs Rifampicin (Aboul Ela 1995) and Paracetamol (Farghaly 2003).

The present results indicate that clarithromycin has cytogenetic effect in the different kinds of cells analyzed.

\section{References}

Aboul Ela, E. I. 1995 Cytogenetic effects of Rifampicin in somatic and germinal cells of the mouse. J. Appl. Toxicol. 15: 325-326.

Allen, J. W., Liang, J. C., Carrano, A. V. and Preston, J. R. 1986. Review of literature on chemical induced aneuploidy in mammalian male germ cells. Mutation Res. 167: 123-137.

Aly, F. A. E. 2001. The Genotoxic effect of the Antibiotic Cefadroxil (Duricef) in somatic cells of the mouse. Bull. NRC, Egypt. 26: 123-131.

Amer, S. M., Ibrahim, A. A. E. and El-Sherbeny, K. M. 1993. Induction of chromosomal aberrations and sister chromatid exchange in vivo by the insecticide Cypermethrin. J. Appl. Toxicol. 13: 341-345.

Delgado, J. N. and Remers, W. A. 1998. Textbook of Organic Medicinal and Pharmaceutical Chemistry. Publishers Philadelphia. New York.

Donya, S. M. 2002. Cytogenetic studies of some cephalosporines antibiotics on mouse germinal cells. Cytologia 67: 33-39.

Evans, E. P., Breckon, G. and Ford, C. E. 1964. An air-drying method for meiotic preparation from mammalian testes. Cytogenetics 3: 289-294.

Fahmy, M. A. and Aly, F. A. E. 1995. The genotoxic effects of Diazepam in somatic and germinal cells of the mouse. Egypt. J. Med. Lab. Sci. 4: 17-26.

Farghaly, A. A. 2003. Mutagenic evaluation of paracetamol in somatic and germ cells of mice. Cytologia 68: 133-139.

$\mathrm{Hu}$, Q. and Zhu, S. 1990. Induction of chromosomal aberrations in male mouse germ cells by uranyl fluoride containing enriched uranium. Mutation Res. 244: 209-214.

Ibrahim, A. A. E. 2003. The genotoxic effect of the Antibiotic cefuroxime (Zinnat) in somatic and germ cells of the mouse. J. Genetic Eng., \& Biotechnol. (NRC) 1: 163-171.

Latt, S. A. 1974. Sister chromatid exchanges, indices of human chromosome damage and repair : detection by fluorescence and induction by mitomycin C. Proc. Natl. Acad. Sci. (USA) 71: 3162-3166.

Laurence, D. R., Bennett, P. N. and Brown, M. J. 1997. Clinical Pharmacology. New York, Edinburgh, London, Madrid, Melbourne, San Francisco and Tokyo.

Mailhes, J. B., Marchetti, F. and Aardema, M. J. 1993. Griseofulvin induced aneuploidy and meiotic delay in mouse oocytes: Effect of dose and harvest time. Mutation Res. 300: 155-163.

McFee, A. F., Lowe, K. and San Sebastian, J. R. 1983. Improved sister chromatid differentiation using paraffin coated bromodeoxyuridine tablets in mice. Mutation Res. 119: 83-88.

Perry, P. and Wolff, S. 1974. New Giemsa method for the differential staining of sister chromatids. Nature (London) 261: $156-158$.

— and Evans, H. J. 1975. Cytologic detection of mutagen carcinogen exposure by sister chromatid exchange. Nature (London) 258: 121-125.

Yosida, T. H. and Amano, K. 1965. Autosomal polymorphism in laboratory bred and wild Norway rats, Rattus norvegicus, found in Misima. Chromosoma 16: 658-667. 